\title{
HUBUNGAN STATUS GIZI DENGAN PERKEMBANGAN BALITA USIA 1-3 TAHUN (Di Posyandu Jaan Desa Jaan Kecamatan Gondang Kabupaten Nganjuk)
}

Lely Khulafa' ur Rosidah ${ }^{1}$, Suleni Harsiwi ${ }^{2}$

Akademi Kebidanan Dharma Husada Kediri Jawa Timur

\begin{abstract}
ABSTRAK
Perkembangan memiliki tahapan yang berurutan mulai dari kemampuan melakukan hal yang sederhana menuju kemampuan melakukan hal yang sempurna dan setiap individu memiliki kecepatan perkembangan yang berbedabeda. Proses percepatan dan perlambatan tersebut dapat dipengaruhi oleh beberapa faktor, yaitu faktor herediter, lingkungan, budaya lingkungan, sosial ekonomi, iklim / cuaca, nutrisi, dan lain-lain. Tujuan penelitian ini adalah untuk mengetahui tentang hubungan status gizi dengan perkembangan balita usia 1-3 tahun di Posyandu Jaan Desa Jaan Kecamatan Gondang Kabupaten Nganjuk.

Penelitian ini menggunakan rancangan korelasi dengan pendekatan cross sectional. Populasinya adalah semua ibu dan balita usia 1-3 tahun di Posyandu Jaan Desa Jaan Kecamatan Gondang Kabupaten Nganjuk, dengan teknik Total sampling didapatkan sampel sejumlah 35 responden. Variabel independent yaitu status gizi balita usia 1-3 tahun dan variabel dependent yaitu perkembangan balita usia 1-3 tahun. Pengambilan data menggunakan observasi BB/TB dan KPSP kemudian diolah dengan editing, coding, scoring, dan tabulating dan dianalisis menggunakan uji Spearman Rank.

Hasil penelitian dari 35 responden didapatkan sebagian besar status gizi balita adalah gizi baik sebanyak 25 responden (71.5\%). Sebagian besar perkembangan balita adalah sesuai sebanyak 23 responden (65.7\%). Berdasarkan hasil uji statistik Spearman Rank didapatkan thitung 3,647 dan bila dibandingkan dengan t tabel $(\alpha=0,025)$ adalah 1,960 maka $\mathrm{t}$ hitung $>\mathrm{t}$ tabel yaitu 3,647 $>1,960$ sehingga $\mathrm{H}_{1}$ diterima artinya ada hubungan antara status gizi dengan perkembangan balita usia 1-3 tahun.

Dari hasil penelitian ini dapat disimpulkan bahwa status gizi akan mempengaruhi perkembangan balita. Dalam pertumbuhan dan perkembangan anak memerlukan zat gizi agar proses pertumbuhan dan perkembangan berjalan dengan baik.
\end{abstract}

Kata Kunci : Status Gizi, Perkembangan, Balita Usia 1-3 Tahun

Korespondensi: Jl. Teratai RT 20 RW 03 Kel.Ngampel Kec.Mojoroto Kota Kediri Hp.085664425144 E-mail: iffat.yakta@gmail.com 


\section{PENDAHULUAN}

Masa balita adalah masa pembentukan dan perkembangan manusia, usia ini merupakan usia yang rawan karena balita sangat peka terhadap gangguan pertumbuhan serta bahaya yang menyertainya. Masa balita disebut juga sebagai masa keemasan, dimana terbentuk dasardasar kemampuan keindraan, berfikir, berbicara serta pertumbuhan mental intelektual yang intensif dan awal pertumbuhan moral.

Perkembangan adalah bertambahnya struktur dan fungsi tubuh yang lebih kompleks dalam kemampuan gerak kasar, gerak halus, bicara dan bahasa serta sosialisasi dan kemandirian (Depkes, 2006:5).

Fase terpenting dalam pertumbuhan dan perkembangan adalah masa bayi dan balita karena pada masa itulah saat paling penting bagi orang tua dalam membangun fondasi pertumbuhan dan perkembangan buah hati. Proses pertumbuhan dan perkembangan pada masa bayi dan balita merupakan proses yang teramat penting dalam menentukan masa depan anak baik secara fisik, mental maupun perilaku (Maryunani, 2010:76).

Salah satu upaya untuk mengetahui adanya penyimpangan pada perkembangan anak adalah dengan deteksi dini, sehingga upaya pencegahan, stimulasi, penyembuhan daan pemulihan dapat diberikan secara benar sesuai dengan indikasinya. Deteksi untuk tumbuh kembang ini merupakan suatu upaya yang perlu didukung, karena merupakan salah satu cara untuk mempersiapkan generasi mendatang yang berkualitas (Yuniarti, 2015:40).
Kualitas anak masa kini merupakan penentu kualitas Sumber Daya Manusia (SDM) di masa yang akan datang. Pembangunan manusia masa depan dimulai dengan pembinaan anak masa sekarang. Untuk mempersiapkan SDM yang berkualitas maka perlu dipersiapkan agar anak dapat tumbuh dan berkembang seoptimal mungkin sesuai dengan kemampuannya.

Nutrisi adalah salah satu komponen yang penting dalam menunjang keberlangsungan proses pertumbuhan dan perkembangan. Nutrisi menjadi kebutuhan untuk tumbuh dan berkembang selama masa pertumbuhan. Dalam nutrisi terdapat kebutuhan zat gizi yang diperlukan untuk pertumbuhan dan perkembangan seperti protein, karbohidrat, lemak, mineral, vitamin, dan air. Apabila kebutuhan nutrisi seseorang tidak atau kurang terpenuhi maka dapat menghambat pertumbuhan dan perkembangannya (Hidayat, 2008:12).

Keadaan gizi merupakan gambaran apa yang dikonsumsi oleh seseorang dalam jangka waktu yang lama. Karena itu, ketersediaan zat gizi di dalam tubuh seseorang termasuk bayi dan balita menentukan keadaan gizi bayi dan balita apakah kurang, optimum atau lebih. Makanan yang diberikan pada bayi dan balita akan digunakan untuk pertumbuhan badan, karena itu status gizi dan pertumbuhan dapat dipakai sebagai ukuran untuk memantau kecukupan gizi bayi dan balita, dimana seluruh pertumbuhan dan kesehatan balita erat kaitannya dengan masukkan makanan yang memadai. Pertumbuhan dan perkembangan yang optimal pada balita memerlukan makanan yang sesuai dengan balita 
yang sedang tumbuh (Maryunani, 2010:258).

Kurangnya asupan makanan balita yang bergizi dan kemampuan orang tua dalam memantau pertumbuhan dan perkembangan balitanya adalah faktor yang paling utama mempengaruhi status gizi balita. Sedangkan faktor yang mempengaruhi status gizi balita adalah ketersediaan pangan di tingkat keluarga, pola asuh keluarga, kesehatan lingkungan, budaya keluarga, dan sosial ekonomi.

Pemantauan Status Gizi (PSG) 2015 menunjukkan hasil yang lebih baik dari tahun sebelumnya. Persentase balita dengan gizi buruk dan sangat pendek mengalami penurunan. Pada tahun ini, PSG dilakukan di 496 kabupaten/kotamadya dengan melibatkan 165.000 balita sebagai sampelnya. Tahun sebelumnya PSG dilakukan hanya di 150 kabupaten/kotamadya dengan jumlah sampel 13.168 balita. Berdasarkan indeks berat badan terhadap usia (BB/U), PSG 2015 menyebut 3,8\% balita mengalami gizi buruk. Angka ini turun dari tahun sebelumnya, yakni $4,7 \%$. Sedangkan berdasarkan indeks tinggi badan terhadap usia (TB/U), balita 'sangat pendek' berkurang dari 10,9\% di tahun 2014 menjadi $10,1 \%$ tahun ini. Balita dengan status pendek pada 2015 tercatat $18,9 \%$, meningkat tipis dari sebelumnya $18 \%$. Berdasarkan indeks berat badan terhadap tinggi badan (BB/TB), PSG 2015 mencatat 3,7\% balita berstatus 'sangat kurus'. Angka ini tidak banyak berubah dari tahun sebelumnya, yakni 3,6\%. Namun jika dibandingkan dengan hasil Riset Kesehatan Dasar (Riskesdas) yang mencapai 5,7\%, angka ini jauh lebih kecil. (Kemenkes RI, 2015)
Dalam pertumbuhan dan perkembangan anak memerlukan zat gizi agar proses pertumbuhan dan perkembangan berjalan dengan baik. Zat-zat gizi yang dikonsumsi anak akan berpengaruh pada status gizinya. Perbedaan status gizi memiliki pengaruh yang berbeda pada setiap perkembangan anak, jika kebutuhan gizi seimbang tidak terpenuhi dengan baik maka pencapaian pertumbuhan dan perkembangan anak akan terhambat. Agar dapat menentukan makanan yang sesuai kebutuhan tubuhnya maka manusia harus belajar dan berlatih sejak dini. Sedangkan makanan yang dikonsumsi hari ini mempunyai peran yang sangat besar dalam menentukan kualitas hidup anak di kemudian hari.

Upaya untuk mendorong perbaikan status kesehatan, yaitu dengan pemberian gizi yang baik diharapkan pertumbuhan dan perkembangan anak akan baik pula, disamping dapat memperbaiki status kesehatan anak. Upaya tersebut dapat dilakukan melalui berbagai kegiatan, di antaranya Upaya Perbaikan Gizi Keluarga (UPGK). Kegiatan UPGK tersebut didorong dan diarahkan pada peningkatan status gizi, khususnya pada masyarakat yang rawan atau memiliki resiko tinggi terhadap kematian atau kesakitan termasuk balita (Hidayat, 2008:4).

\section{METODE PENELITIAN}

- Menurut peneliti, penelitian ini menggunakan penelitian analitik yaitu dengan menggunakan desain korelasi. Korelasi adalah hubungan antar variabel. Menurut peneliti, penelitian ini menggunakan penelitian analitik yaitu dengan menggunakan desain korelasi. Korelasi adalah hubungan 
antar variabel. Dengan menggunakan pendekatan Cross Sectional.

Populasi dalam penelitian ini adalah semua ibu \& balita usia 1-3 tahun di Posyandu Jaan Desa Jaan Kecamatan Gondang Kabupaten Nganjuk sebanyak 35 balita.

Sampel dalam penelitian ini adalah semua ibu \& balita usia 1-3 tahun di Posyandu Jaan Desa Jaan Kecamatan Gondang Kabupaten Nganjuk sebanyak 35 balita.
Dalam penelitian ini, variabel bebas adalah status gizi balita usia 1-3 tahun di Posyandu Jaan Desa Jaan Kecamatan Gondang Kabupaten Nganjuk.

Dalam penelitian ini, variabel terikat adalah perkembangan balita usia 1-3 tahun di Posyandu Jaan Desa Jaan Kecamatan Gondang Kabupaten Nganjuk.

\section{HASIL}

a. Karakteristik Responden Berdasarkan Umur

Tabel 1 : Karakteristik Responden Berdasarkan Kelas Umur Balita Usia 1-3 Tahun di Posyandu Jaan Desa Jaan Kecamatan Gondang Kabupaten Nganjuk Tanggal 14 Mei 2016

\begin{tabular}{|c|c|c|c|}
\hline No & Umur & Jumlah & Prosentase (\%) \\
\hline 1 & $12-14$ bulan & 7 & 20 \\
\hline 2 & $15-17$ bulan & 2 & 5,7 \\
\hline 3 & $18-20$ bulan & 5 & 14,3 \\
\hline 4 & $21-23$ bulan & 4 & 11,4 \\
\hline 5 & $24-29$ bulan & 5 & 14,3 \\
\hline 6 & $30-36$ bulan & 12 & 34,3 \\
\hline \multicolumn{2}{|c|}{ Jumlah } & 35 & 100 \\
\hline
\end{tabular}

b. Karakteristik Responden Berdasarkan Jenis Kelamin

Tabel 2 : Karakteristik Responden Berdasarkan Jenis Kelamin Balita Usia 1-3 Tahun di Posyandu Jaan Desa Jaan Kecamatan Gondang Kabupaten Nganjuk

\begin{tabular}{|c|l|c|c|}
\hline No & Jenis Kelamin & Jumlah & Prosentase (\%) \\
\hline 1 & Laki-laki & 21 & 60 \\
\hline 2 & Perempuan & 14 & 40 \\
\hline \multicolumn{2}{|c|}{ Jumlah } & 35 & 100 \\
\hline
\end{tabular}

c. Karakteristik Ibu Responden Berdasarkan Umur

Tabel 3: Karakteristik Ibu Responden Berdasarkan Umur di Posyandu Jaan Desa Jaan Kecamatan Gondang Kabupaten Nganjuk

\begin{tabular}{|c|l|c|c|}
\hline No & \multicolumn{1}{|c|}{ Umur } & Jumlah & Prosentase $(\%)$ \\
\hline 1 & $<20$ tahun & 3 & 8,6 \\
\hline 2 & $20-35$ tahun & 28 & 80 \\
\hline
\end{tabular}




\begin{tabular}{|l|l|l|l|}
\hline 3 & $>35$ tahun & 4 & 11,4 \\
\hline
\end{tabular}

d. Karakteristik Ibu Responden Berdasarkan Tingkat Pendidikan

Tabel 4: Karakteristik Ibu Responden Berdasarkan Tingkat Pendidikan di Posyandu Jaan Desa Jaan Kecamatan Gondang Kabupaten Nganjuk

\begin{tabular}{|c|l|c|c|}
\hline No & \multicolumn{1}{|c|}{ Pendidikan } & Jumlah & Prosentase (\%) \\
\hline 1 & SD/MI & 6 & 17,1 \\
\hline 2 & SMP/MTs & 12 & 34,3 \\
\hline 3 & SMA Sederajat & 17 & 48,6 \\
\hline 4 & Akademi/Perguruan Tinggi & 0 & 0 \\
\hline 5 & Tidak Bersekolah & 0 & 0 \\
\hline \multicolumn{2}{|c|}{ Jumlah } & 35 & 100 \\
\hline
\end{tabular}

e. Karakteristik Ibu Responden Berdasarkan Pekerjaan

Tabel IV.5 : Karakteristik Ibu Responden Berdasarkan Pekerjaan di Posyandu Jaan Desa Jaan Kecamatan Gondang Kabupaten Nganjuk

\begin{tabular}{|c|l|c|c|}
\hline No & \multicolumn{1}{|c|}{ Pekerjaan } & Jumlah & Prosentase (\%) \\
\hline 1 & Swasta & 1 & 2,9 \\
\hline 2 & Wiraswasta & 0 & 0 \\
\hline 3 & PNS & 0 & 0 \\
\hline 4 & IRT & 32 & 91,4 \\
\hline 5 & Tani & 2 & 5,7 \\
\hline 6 & Lain-lain & 0 & 0 \\
\hline \multicolumn{2}{|c|}{ Jumlah } & 35 & 100 \\
\hline
\end{tabular}

f. Karakteristik Responden Berdasarkan Penghasilan Tiap Bulan Orang Tua

Tabel 6 Karakteristik Responden Berdasarkan Penghasilan Tiap Bulan Orang Tua di Posyandu Jaan Desa Jaan Kecamatan Gondang Kabupaten Nganjuk

\begin{tabular}{|c|l|c|c|}
\hline No & Penghasilan & Jumlah & Prosentase (\%) \\
\hline 1 & $<$ Rp. 500.000 & 5 & 14,3 \\
\hline 2 & Rp. 500.000-1000.000 & 14 & 40 \\
\hline 3 & $>$ Rp. 1000.000 & 16 & 45,7 \\
\hline \multicolumn{2}{|c|}{ Jumlah } & 35 & 100 \\
\hline
\end{tabular}

g. Karakteristik Responden Berdasarkan Jumlah Anak

Tabel IV.7 Karakteristik Responden Berdasarkan Jumlah Anak di Posyandu Jaan Desa Jaan Kecamatan Gondang Kabupaten Nganjuk

\begin{tabular}{|l|l|l|l|}
\hline No & Jumlah Anak & Jumlah & Prosentase (\%) \\
\hline
\end{tabular}




\begin{tabular}{|c|l|c|c|}
\hline 1 & 1 & 20 & 57,1 \\
\hline 2 & 2 & 12 & 34,3 \\
\hline 3 & $>3$ & 3 & 8,6 \\
\hline \multicolumn{2}{|c|}{ Jumlah } & 35 & 100 \\
\hline
\end{tabular}

1. Data Khusus

a. Status Gizi Balita

Tabel 8 : Distribusi Frekuensi Status Gizi Balita Usia 1-3 Tahun di Posyandu Jaan Desa Jaan Kecamatan Gondang Kabupaten Nganjuk

\begin{tabular}{|c|l|c|c|}
\hline No & \multicolumn{1}{|c|}{ Status Gizi } & Frekuensi & Prosentase (\%) \\
\hline 1 & Gizi Lebih & 4 & 11,4 \\
\hline 2 & Gizi Baik & 25 & 71,5 \\
\hline 3 & Gizi Kurang & 5 & 14,3 \\
\hline 4 & Gizi Buruk & 1 & 2,9 \\
\hline \multicolumn{2}{|c|}{ Jumlah } & 35 & 100 \\
\hline
\end{tabular}

b. Perkembangan Balita

Tabel 9: Distribusi Frekuensi Perkembangan Balita Usia 1-3 Tahun di Posyandu Jaan Desa Jaan Kecamatan Gondang Kabupaten Nganjuk

\begin{tabular}{|c|l|c|c|}
\hline No & Perkembangan & Frekuensi & Prosentase (\%) \\
\hline 1 & Sesuai & 23 & 65,7 \\
\hline 2 & Meragukan & 9 & 25,7 \\
\hline 3 & Penyimpangan & 3 & 8,6 \\
\hline & Jumlah & 35 & 100 \\
\hline
\end{tabular}

2. Hubungan Status Gizi dengan Perkembanga Balita

Tabel 10: Tabel Silang antara Status Gizi dengan Perkembangan Balita Usia 1-3 Tahun di Posyandu Jaan Desa Jaan Kecamatan Gondang Kabupaten Nganjuk

\begin{tabular}{|c|c|c|c|c|c|c|c|c|c|}
\hline \multirow{3}{*}{$\begin{array}{l}\mathrm{N} \\
\mathrm{O}\end{array}$} & \multirow{3}{*}{$\begin{array}{c}\text { Status } \\
\text { Gizi }\end{array}$} & \multicolumn{6}{|c|}{ Perkembangan } & \multicolumn{2}{|c|}{ Jumlah } \\
\hline & & \multicolumn{2}{|c|}{ Sesuai } & \multicolumn{2}{|c|}{ Meragukan } & \multicolumn{2}{|c|}{ Penyimpangan } & & \\
\hline & & $\mathrm{f}$ & $\%$ & $\mathrm{f}$ & $\%$ & $\mathrm{f}$ & $\%$ & $\mathrm{f}$ & $\%$ \\
\hline 1 & Lebih & 3 & 8,6 & 1 & 2,9 & 0 & 0 & 4 & 11,4 \\
\hline 2 & Baik & 20 & 57,1 & 5 & 14,3 & 0 & 0 & 25 & 71,4 \\
\hline 3 & Kurang & 0 & 0 & 3 & 8,6 & 2 & 5,7 & 5 & 14,3 \\
\hline 4 & Buruk & 0 & 0 & 0 & 0 & 1 & 2,9 & 1 & 2,9 \\
\hline & Jumlah & 23 & 65,7 & 9 & 25,8 & 3 & 8,6 & 35 & 100 \\
\hline
\end{tabular}




\section{PEMBAHASAN}

\section{Status Gizi Balita Usia 1-3 Tahun} di Posyandu Jaan Desa Jaan Kecamatan Gondang Kabupaten Nganjuk

Berdasarkan Tabel 8 menunjukkan dari 35 responden yang diteliti, sebanyak 4 responden $(11,4 \%)$ kategori gizi lebih, sebanyak 25 responden (71,5\%) kategori gizi baik, sebanyak 5 responden $(14,3 \%)$ kategori gizi kurang, dan sebanyak 1 responden $(2,9 \%)$ kategori gizi buruk. Dari data tersebut diketahui bahwa satatus gizi balita di Posyandu Jaan Desa Jaan Kecamatan Gondang Kabupaten Nganjuk sebagian besar adalah baik

Status gizi adalah keadaan yang ditunjukkan sebagai konsekuensi dari keseimbangan antara zat gizi yang masuk ke tubuh dan yang diperlukan (Maryunani, 2010:258). Status gizi adalah ekspresi dari keadaan keseimbangan dalam bentuk variable tertentu, atau perwujudan dari nutrient tertentu (Supariasa, 2013:18).

Keadaan gizi merupakan gambaran apa yang dikonsumsi oleh seseorang dalam jangka waktu yang cukup lama. Karena itu, ketersediaan zat gizi di dalam tubuh seseorang menentukan keadaan gizi apakah kurang, optimum atau lebih (Maryunani, 2010:258).

Masa balita merupakan masa yang penting yang perlu diperhatikan bagi orang tua yang memiliki balita, sebab pada masa ini status gizi balita berpengaruh pada pertumbuhan dan perkembangan balita. Balita merupakan masa keemasan karena jika balita mengalami kurang gizi maka anak menganggu pertumbuhan dan perkembangannya, biasanya balita yang kurang gizi cenderung lebih kurus dan pendek dari pada teman sebayanya yang gizinya normal. Selain itu kurang gizi dapat menganggu perkembangan kognitifnya. Balita akan lamban dalam berfikir dan memahami sesuatu.

Dalam penelitian ini, terdapat beberapa faktor yang mempengaruhi status gizi balita, diantaranya adalah pendapatan orang tua. Berdasarkan Tabel IV.6 menunjukkan dari 35 responden yang diteliti, didapatkan 16 responden $(45,7 \%)$ dengan penghasilan orang tua tiap bulan sebesar >Rp. 1000.000.

Permasalahan ekonomi adalah keterbatasan penghasilan keluarga turut menentukan mutu makanan yang disajikan. Tidak dapat disangkal bahwa penghasilan keluarga akan turut menentukan hidangan yang disajikan untuk keluarga sehari-hari, baik kualitas maupun jumlah makanan (Marimbi,2010:97).

Balita yang memiliki orang tua yang berpenghasilan kurang akan mempengaruhi daya beli pangan, sehingga asupan nutrisi yang sangat mempengaruhi status gizi balita menjadi tidak tercukupi. Ketersediaaan bahan pangan dalam keluarga akan mempengaruhi kualitas dan kuantitas makanan yang dikonsumsi anggota keluarga sehingga yang dikonsumsi menjadi tidak terjamin kandungan gizinya yang akan mengakibatkan gangguan pada status gizi. Jadi semakin tinggi penghasilan, maka akan semakin tinggi juga kemampuan dalam menyediakan 
bahan pangan yang bergizi untuk keluarganya.

Pada balita yang berasal dari keluarga yang mampu, kondisi ini disebabkan karena perilaku keluarga dalam memberikan asupan nutrisi pada anak cenderung permisif, dalam arti keluarga membiarkan anak mengkonsumsi makanan dengan angka kecukupan gizi yang kurang misalnya lebih mengutamakan jajan dibandingkan dengan asupan makanan pokok akibatnya kebutuhan gizi anak tidak tercukupi. Kondisi ini tentunya menjadikan anak tidak dapat tumbuh dengan baik walaupun secara status sosial ekonomi sebenarnya mereka berasal dari keluarga cukup.

Selain penghasilan orang tua, secara tidak langsung jumlah anak juga mempengaruhi status gizi balita. Dari hasil penelitian yang telah dilakukan dapat dilihat $\begin{array}{lll}\text { berdasarkan } & \text { Tabel } & \text { IV.7 }\end{array}$ menunjukkan dari 35 responden yang diteliti, didapatkan 20 responden $(57,1 \%)$ dengan orang tua yang mempunyai 1 anak. Pada keluarga dengan jumlah anak yang banyak anak mengakibatkan selain kurangnya kasih sayang dan perhatian pada anak juga kebutuhan primer seperti makan, sandang dan perumahan yang terpenuhi (Atom, 2010).

Jarak kelahiran yang terlalu rapat dan jumlah anak yang terlalu banyak dapat mempengaruhi pada banyaknya perhatian dan kasih sayang orang tua pada anaknya. Selain itu juga mempengaruhi asupan zat gizi dalam keluarga yang mengakibatkan kebutuhan utamanya kurang terpenuhi karena anak harus berbagi dengan saudaranya dalam hal makanan dan kebutuhan pokok lainnya. Apabila ketersediaan pangan di dalam keluarga sedikit dan memiliki anak yang banyak akan lebih perpengaruh pada status gizi balita. Pada responden yang diteliti, sebagian besar hanya memiliki 1-2 anak saja, sehingga pendapatan orang tua masih cukup untuk memenuhi kebutuhan balitanya, serta perhatian dan kasih sayang dari orang tua pada anaknya yang cukup sehingga kecukupan gizi anak tercukupi dan menjadikan status gizi anak menjadi baik. Pekerjaan juga dapat mempengaruhi pengetahuan yang dimilikinya, dengan bekerja dapat berinteraksi dengan lingkungan dan saling bertukar fikiran sehingga dengan bekerja seseorang akan mendapatkan pengalaman yang akan memperbanyak pengetahuannya. Apabila seorang ibu tidak memiliki pekerjaan atau sebagai ibu rumah tangga maka ibu akan lebih banyak memiliki waktu luang dari pada ibu yang bekerja. Dengan banyak waktu luang ibu dapat lebih banyak waktu untuk mengurus anak dan menemani anaknya dirumah sehingga ibu rutin datang ke posyandu setiap bulan untuk menimbangkan anaknya, dari pada ibu yang bekerja yang tidak memiliki waktu luang.

2. Perkembangan Balita Usia 1-3 Tahun di Posyandu Jaan Desa Jaan Kecamatan Gondang Kabupaten Nganjuk

Berdasarkan Tabel 9 menunjukkan dari 35 responden yang diteliti, sebagian besar perkembangan balita adalah sesuai sebanyak 23 responden $(65,7 \%)$.

Perkembangan adalah perubahan secara berangsur-angsur dan bertambah sempurnanya fungsi 
alat tubuh, meningkat dan meluasnya kapasitas seseorang melalui pertumbuhan, kematangan atau kedewasaan, dan pembelajaran (Hidayat, 2008:26).

Masalah perkembangan pada anak merupakan masalah yang sangat penting karena untuk mengetahui kelainan perkembangan pada anak, agar diagnosis ataupun pemulihannya dapat dilakukan lebih awal sehingga perkembangan anak berlangsung seoptimal mungkin. Anak yang memiliki perkembangan normal, hal ini disebabkan karena stimulasi anak tidak hanya diberikan oleh orang tua akan tetapi juga diberikan lingkungannya. Peran lingkungan anak sangat penting dalam membentuk perkembangan. Apabila kondisi lingkungan yang sehat dapat menyebabkan balita berkembang dengan baik sedangkan kondisi lingkungan yang tidak sehat dapat menyebabkan anak berkembang menjadi tidak sehat. Sebagai contoh anak yang berembang dengan lingkungan yang penuh kasih sayang dapat menstimulasi anak menjadi lebih baik. Sedangkan pada anak yang berkembang pada lingkungan yang tanpa kasih sayang dalam arti tidak peduli maka akan menyebabkan anak jarang mendapatkan stimulasi sehingga perkembangannya menjadi terhambat.

Salah satu yang mempengaruhi perkembangan adalah umur ibu. Berdasarkan Tabel 3 menunjukkan dari 35 responden yang diteliti, sebagian besar umur ibu responden adalah umur 20-35 tahun sebanyak 28 orang $(80 \%)$.

Semakin cukup umur, tingkat kematangan dan kekuatan seseorang akan lebih matang dalam berfikir dan bekerja. Hal ini sebagai akibat dari pengalaman dan kematangan jiwanya (Wawan \& Dewi, 2010:17).

Pada kisaran umur 20-35 tahun seseorang sudah matang dalam berfikirnya sehingga dengan kematangan umur seseorang dan berfikir maka ibu akan lebih mudah menerima pengetahuan dan informasi termasuk pengetahuan tentang menstimulasi perkembangan anak dan ibu dapat menerapkannya dirumah. Pada ibu yang umurnnya $>35$ tahun cenderung kurang memperhatikan dalam stimulasi perkembangan anaknya karena ibu biasanya lebih mementingkan pekerjaan yang lain dari pada mengurus anaknya dan menstimulasi perkembangan anak sehingga pada anak yang usia ibunya $>35$ tahun perkembangannya terhambat.

Selain umur ibu, perkembangan juga dipengaruhi oleh tingkat pendidikan ibu. Berdasarkan Tabel 4 menunjukkan dari 35 responden yang diteliti, sebagian besar tingkat pendidikan ibu responden adalah SMA Sederajat sebanyak 17 orang (48,6\%).

Makin tinggi tingkat pendidikan seseorang, makin mudah menerima informasi sehingga makin banyak pula pengetahuan yang dimiliki. Sebaliknya pendidikan yang kurang akan menghambat perkembangan sikap seseorang terhadap nilai-nilai yang baru diperkenalkan (Wawan \& Dewi, 2010:17).

Semakin tinggi pendidikan ibu balita maka pengetahuannya akan lebih luas, sebaliknya jika ibu balita memiliki pendidikan yang rendah maka pengetahuannya menjadi sempit. Hal ini dapat mempengaruhi sikap dan perilaku 
ibu balita dalam menstimulasi perkembangan balita sesuai usianya.

3. Hubungan Status Gizi dengan Perkembangan Balita Usia 1-3 Tahun di Posyandu Jaan Desa Jaan Kecamatan Gondang Kabupaten Nganjuk

Dalam penelitian ini, perhitungan uji statistik data yang digunakan adalah Spearman Rank. Dari uji statistik analisa data diperoleh hasil signifikasi sebesar $3,647$ [ $\mathrm{t}>1,960]$ yang berarti ada hubungan antara status gizi dengan perkembangan balita usia 1-3 tahun. Adapun koefisien korelasi sebesar 0,536 menunjukkan korelasi yang cukup kuat antara status gizi balita dengan perkembangan balita usia 1-3 tahun.

Berdasarkan Tabel 10 dapat diketahui bahwa dari 35 responden di Posyandu Jaan Desa Jaan Kecamatan Gondang Kabupaten Nganjuk terdapat 20 responden $(57,1 \%)$ dengan perkembangan sesuai yang mempunyai gizi baik dan 5 responden $(14,3 \%)$ dengan perkembangan meragukan yang mempunyai gizi baik.

Status gizi adalah keadaan kesehatan sebagai hasil masukan zat gizi (Maryunani, 2010:258). Konsumsi makanan yang bergizi dapat menentukan tercapainya tingkat kesehatan. Seseorang dapat mengetahui bagaimana konsumsi makanan yang bergizi baik dengan cara mengetahuinya. Apabila seseorang kurang mengetahui tentang gizi dan konsumsinya maka akan mempengaruhi kondisi gizinya karena seseorang tersebut akan mengkonsumsi makanan sesuka hatinya tanpa memperhitungkan asupan gizi yang baik. Jadi status gizi balita dikatakan baik yakni apabila terdapat keseimbangan antara zat gizi yang masuk dalam tubuh dan yang diperlukan dalam kegiatan sehari-hari.

Dalam penelitian ini, terdapat beberapa faktor yang mempengaruhi status gizi balita, diantaranya adalah pendapatan orang tua. Berdasarkan Tabel IV.6 menunjukkan dari 35 responden yang diteliti, didapatkan 16 responden $(45,7 \%)$ dengan penghasilan orang tua tiap bulan sebesar >Rp. 1000.000.

Permasalahan ekonomi adalah keterbatasan penghasilan keluarga turut menentukan mutu makanan yang disajikan. Tidak dapat disangkal bahwa penghasilan keluarga akan turut menentukan hidangan yang disajikan untuk keluarga sehari-hari, baik kualitas maupun jumlah makanan (Marimbi,2010:97).

Pendapatan merupakan dasar penghidupan, sebab dengan pendapatan seseorang dapat memenuhi kebutuhannya, baik material maupun kebutuhan spiritual. Setiap orang yang bekerja akan mendapatkan upah. Sedangkan besar kecilnya pendapatan seseorang berpengaruh terhadap besar kecilnya kebutuhan yang akan dipenuhi.

Selain penghasilan orang tua, secara tidak langsung jumlah anak juga mempengaruhi status gizi balita. Dari hasil penelitian yang telah dilakukan dapat dilihat Berdasarkan Tabel IV.7 menunjukkan dari 35 responden yang diteliti, didapatkan 20 responden $(57,1 \%)$ dengan orang tua yang mempunyai 1 anak. Jumlah anak adalah jumlah 
keturunan yang dilahirkan dari seorang ibu. Jumlah anak yang dilahirkan akan mempengaruhi seseorang dalam menentukan pilihannya untuk kesejahteraan keluarganya (Santoso, 2009).

Keluarga/ibu yang mempunyai banyak anak akan menimbulkan banyak masalah bagi keluarga tersebut, jika penghasilan tidak mencukupi kebutuhan. Keluarga yang mempunyai banyak anak juga menyebabkan terbaginya kasih sayang dan perhatian yang tidak merata pada setiap anak.

Banyaknya anak dalam keluarga mengakibatkan beratnya beban tanggung keluarga baik secara sosial (pengasuhan anak), maupun ekonomi yang selanjutnya berpengaruh terhadap status gizi anak. Jumlah anak yang dilahirkan oleh seorang ibu dan jarak anak yang terlalu dekat berhubungan erat dengan beban pekerjaan rumah tangga dan juga berpengaruh terhadap kemampuan fisiologis tubuh ibu menyediakan nutrisi bagi balitanya.

Selain pendapatan dan jumlah anak yang dapat mempengaruhi status gizi, faktor lain yang juga mempengaruhi status gizi adalah pekerjaan orang tua. Berdasarkan Tabel .5 menunjukkan dari 35 responden yang diteliti, sebagian besar pekerjaan ibu responden adalah IRT sebanyak 32 orang $(91,4 \%)$

Pekerjaan adalah kebutuhan yang harus dilakukan terutama untuk menunjang kehidupannya dan kehidupan keluarganya. Bekerja umumnya kegiatan yang menyita waktu. Bekerja bagi ibuibu akan mempunyai pengaruh terhadap kehidupan keluarganya (Wawan \& Dewi, 2010:16).
Ibu yang tidak bekerja dalam keluarga dapat mempengaruhi asupan gizi balita karena ibu berperan sebagai pengasuh dan pengatur konsumsi makanan anggota keluarga. Ibu yang bekerja tidak memiliki waktu yang cukup untuk mengasuh dan merawat anaknya sehingga anaknya dapat menderita gizi kurang.

Kehidupan ekonomi keluarga akan lebih baik pada keluarga dengan ibu bekerja dibandingkan dengan keluarga yang hanya menggantungkan ekonomi pada kepala keluarga atau ayah. Kehidupan ekonomi keluarga yang lebih baik akan memungkinkan keluarga mampu memberikan perhatian yang layak bagi asupan gizi balita.

Status gizi dapat mempengaruhi perkembangan balita, berdasrakan hasil dari tabel 10 Responden dengan perkembangan penyimpangan yang mempunyai status gizi kurang sebanyak 2 responden $(2,9 \%)$, dan responden dengan perkembangan menyimpang yang mempunyai status gizi buruk sebanyak 1 responden $(2,9 \%)$.

Keadaan gizi merupakan gambaran apa yang dikonsumsi oleh seseorang dalam jangka waktu yang lama. Karena itu, ketersediaan zat gizi di dalam tubuh seseorang termasuk bayi dan balita menentukan keadaan gizi bayi dan balita apakah kurang, optimum atau lebih. Makanan yang diberikan pada bayi dan balita akan digunakan untuk pertumbuhan badan, karena itu status gizi dan pertumbuhan dapat dipakai sebagai ukuran untuk memantau kecukupan gizi bayi dan balita, dimana seluruh pertumbuhan dan kesehatan balita 
erat kaitannya dengan masukkan makanan yang memadai. Pertumbuhan dan perkembangan yang optimal pada balita memerlukan makanan yang sesuai dengan balita yang sedang tumbuh (Maryunani, 2010:258).

\section{SIMPULAN}

Status gizi responden di Posyandu Jaan Desa Jaan Kecamatan Gondang Kabupaten Nganjuk sebagian besar gizi baik yaitu 25 responden ( $71.5 \%)$.

\section{DAFTAR PUSTAKA}

Andriana, Dian. 2011. Tumbuh Kembang dan Terapi Bermain Pada Anak. Jakarta : Salemba Medika.

Arikunto, Suharsimi. 2010. Prosedur Penelitian Suatu Pendekatan Praktik. Jakarta : Rineka Cipta.

Depkes, RI. 2012. Stimulasi, Deteksi dan Intervesi Dini Tumbuh Kembang Anak Ditingkat Pelayanan Kesehatan Dasar. Jakarta : Bakti Husada

Dewi, Ns. Rizki Cintya, Oktiawati, Ns. Anisa, \& Saputri, Lintang Dewi. 2015. Teori dan Konsep Tumbuh Kembang Bayi, Toddler, Anak dan Usia Remaja . Jakarta : Nuha Medika.

Hidayat, A. Aziz Alimul. 2008. Ilmu Kesehatan Anak Untuk Pendidikan Kebidanan. Jakarta : Salemba Medika. 2008.

Pengantar Kebutuhan Dasar Manusia. Jakarta : Salemba Medika.

2011.

Metode Penelitian Keperawatan dan Teknik

Analisi Data. Jakarta : Salemba Medika.
Perkembangan responden di Posyandu Jaan Desa Jaan Kecamatan Gondang Kabupaten Nganjuk sebagian besar sesuai yaitu 23 responden $(65.7 \%)$.

Ada hubungan antara status gizi dengan perkembangan balita usia 1-3 tahun di Posyandu Jaan Desa Jaan Kecamatan Gondang Kabupaten Nganjuk. Berdasarkan analisa hasil uji statistik dengan menggunakan Spearman Rank didapatkan t hitung $>\mathrm{t}$ tabel yaitu $3,647>1,960$ maka menunjukkan $\mathrm{H} 1$ diterima

\section{Riset Keperawatan dan Teknik}

Penulisan

Ilmiah. Jakarta : Salemba Medika.

Marimbi, Hanum. 2010. Tumbuh Kembang, Status Gizi \& Imunisasi Dasar Pada Balita. Yogyakarta : Nuha Medika. Maryunani, Anik. 2010. Ilmu Kesehatan Anak Dalam Kebidanan. Jakarta : Trans Info Media.

Notoatmodjo, Soekidjo. 2010. Metode Penelitian Kesehatan. Jakarta : Rineka Cipta.

. 2012. Metodologi Penelitian Kesehatan. Jakarta :Rineka

Cipta.

Nursalam. 2013. Metodologi Penelitian Ilmu Keperawatan . Jakarta : Salemba Medika.

Proverawati, Atikah \& Wati, Erna Kusuma. 2011. Ilmu Gizi Untuk Keperawatan dan Gizi Kesehatan. Yogyakarta : Nuha Medika.

Septiari, Bety Bea. 2012. Mencetak Balita Cerdas dan Pola Asuh Orang Tua. Yogyakarta : Nuha Medika.

Setiadi. 2007. Konsep dan Penulisan Riset Keperawatan. Yogyakarta : Graha Ilmu. Sugiyono. 2012. Metode Penelitian Administrasi. Bandung : Alfabeta 
Supariasa, I. Dewi Nyoman, Bakri, Bachyar \& Fajar, Ibnu. 2013. Penilaian Status Gizi. Jakarta : EGC

Susilaningrum, Rekawati, Nursalam, \& Utami, Sri. 2013. Asuhan Keperawatan Bayi dan Anak Untuk Perawat dan Bidan. Jakarta : Salemba Medika

Wawan A., \& Dewi M. 2010. Teori Dan Pengukuran Pengetahuan, Sikap, Dan Prilaku Manusia. Yogyakarta:Nuha Medika.

Yuniarti, Sri. 2015. Asuhan Tumbuh Kembang Neonatus Bayi-Balita dan Anak Pra-Sekolah. Bandung : Refika Aditama.

Atom. 2011. Status Gizi Balita Indonesia Masih Memprihatinkan. Avaible from : http://berbagigizi.blogspot.com/2011/01/st atus-gizi-balita-masih.html [Diakses tanggal 27 Mei 2016].

KemenkesRI. 2015. Pemantauan Status Gizi Dilakukan di Seluruh Kabupaten/ Kota di Indonesia. Avaible from: http://www.kemenkesRI.go.id [Diakses tanggal 25 April 2016].

Santoso. 2009. Pengertian Anak. Avaible from: http://www.santoso.blog.frienster .com [Diakses tanggal 19 Juli 2016]

Surabayanews. 2015. Dua Persen Balita di Jawa Timur Alami Gizi Buruk. Avaible from : http://www.surabayanews.co.id [Diakses tanggal 25 April 2016].

Wordpress. 2012. Hubungan Umur dan Tingkat Pendidikan Avaible from : http://www.aperlindraha.wordpress.com

[Diakses tanggal 20 Juli 2016] 
Jurnal Kebidanan Dharma Husada Kediri Vol.6, No.2 April 2017 | 37 